\title{
Historia medycyny na pograniczu dziedzin. Rozważania na marginesie książki Medicina, antiqua mediaevalis et moderna. Historia - filozofia - religia, red. S. Konarska-Zimnicka, L. Kostuch i B. Wojciechowska, Kielce 20 I9
}

\author{
History of Medicine at the Intersection of Disciplines. \\ Reflections on the Margins of Medicina, antiqua \\ mediaevalis et moderna. Historia - filozofia - religia \\ [Medicina, antiqua mediaevalis et moderna. History - \\ Philosophy - Religion], ed. by S. Konarska-Zimnicka, \\ L. Kostuch and B. Wojciechowska, Kielce 20 I 9
}

The article discusses the status of the history of medicine at the intersection of disciplines, with reference to the edited volume: Medicina, antiqua mediaevalis et moderna. Historia - filozofia - religia [Medicina, antiqua mediaevalis et moderna. History - Philosophy Religion] (ed. by S. Konarska-Zimnicka, L. Kostuch and B. Wojciechowska, Kielce 2019). The author focuses on the ancient idea of the unity of body and soul to draw attention to the dependence of medical practices on cultural conditions, using the example of the recipe for headache from Plato's Charmides and the articles in Medicina, antiqua mediaevalis et moderna.

Keywords: history of medicine, philosophy, interdisciplinarity

Słowa kluczowe: historia medycyny, filozofia, interdyscyplinarność

Interdyscyplinarny charakter historii medycyny pozwala na przyjmowanie różnorodnych perspektyw badawczych oraz korzystanie z dorobku wielu dyscyplin naukowych, co realizują autorzy artykułów składających się na książkę Medicina, antiqua mediaevalis et moderna. Historia - filozofia - religia ${ }^{1}$. Publikacja jest wynikiem interdyscyplinarnej konfe-

1 Medicina antiqua, medievalis et moderna. Historia - filozofia - religia, red. S. Konarska-Zimnicka, L. Kostuch i B. Wojciechowska, Kielce 2019. 
rencji poświęconej historii medycyny, zorganizowanej 29-30 maja 2018 r. przez Instytut Historii Uniwersytetu Jana Kochanowskiego w Kielcach oraz Oddział Kielecki Polskiego Towarzystwa Historycznego². Książka zawiera dwadzieścia trzy artykuły ułożone chronologicznie według swojej tematyki, z czego dwanaście z nich przypada na starożytność i średniowiecze, a jedenaście na czasy nowożytne. Poza historią autorzy tekstów sięgają w swoich badaniach po dokonania dziedzin takich jak: filologia klasyczna (Krzysztof Narecki, Śmierć Heraklita z Efezu w starożytnej legendzie; Anna Pająkowska-Bouallegui, Jak cesarz rzymski Julian Apostata dbał o zdrowie?), epigrafika (Elwira Kaczyńska, Najstarsza umowa gwarantująca bezpłatną usługę medyczną), językoznawstwo (Krzysztof Tomasz Witczak, Łacińskie nazwy chorób pochodzenia indoeuropejskiego), etnolingwistyka (Marzena Marczewska, Choroba - obraz utrwalony w tekstach folkloru polskiego), etnografia (Krzysztof Paweł Woźniak, Bulanda i jego karpaccy pobratymcy. Lecznicze praktyki magiczne owczarzy karpackich w XIX i XX wieku), arabistyka (Paulina B. Lewicka, Co robić, gdy nie ma lekarza. Arabski podręcznik medyczny z czternastowiecznego Kairu) czy teologia biblijna (Anna Maria Wajda, Sposoby zapobiegania chorobom, zabiegi lecznicze $i$ lekarstwa wzmiankowane w Biblii). Przyjęty przez redakcję szeroki zakres czasowo-terytorialny pozwala na śledzenie rozwoju myśli medycznej poprzez szereg różnych kontekstów. Zawarte w tomie teksty zabierają czytelnika w czasy biblijne, do antycznej Grecji i Rzymu, Cesarstwa Bizantyjskiego i średniowiecza (ze szczególnym uwzględnieniem Krakowa, Kairu i Beauvais), poprzez XVI i XVII w. na ziemiach polskich, w Królestwie Węgier, a także w Niderlandach, po Polskę XVIII, XIX i XX . Redaktorzy podkreślają, że zależało im na „uwidocznieniu medycznego dziedzictwa i wpływów kulturowych" (s. 7). Znaczna część artykułów zwraca szczególną uwagę na konteksty obyczajowo-społeczne obranych tematów (Jacek Pielas, Chorzy umysłowo w prawie ziemskim i praktyce funkcjonowania rodzin szlacheckich w Rzeczypospolitej XVI-XVIII wieku. Zarys problematyki i perspektywy badawcze; Tünde Lengyelová, Úspešné vyliečenie neplodnosti v 16. Storoči; Małgorzata Delimata-Proch, Choroby oraz wypadki dzieci w świetle księgi "Cudów y łask za przyczyną (...) Józefa świętego (...) w Kollegiacie Kalliskiey” Stanisława Józefa Kłossowskiego; Anna Głusiuk, Ciąża, poród i powikłania po porodzie w traktacie "O chorobach kobiet" Metrodory z Bizancjum), wiele skupia się na sposobie postrzegania danego konceptu w wybranym okresie lub dziele (Lucyna Kostuch, Elephantus medicus. Zwierzę $w$ antycznej medycynie; Igor Rosa, Od Scytii do Sarmacji. Castoreum w tradycji medycznej antyku i średniowiecza; Beata Wojciechowska, Poczęcie człowieka w świetle Speculum Naturale Wincentego z Beauvais (ok. 1194-1264); Sylwia Konarska-Zimnicka, Jatromatematyka w optyce twórczości krakowskich uczonych późnego średniowiecza. Przyczynek do badań; Wioletta Szafarczyk, Wino jako płynny lek w świetle herbarzy staropolskich). Joanna Usakiewicz zastanawia się nad relacją między medycyną a filozofią w dziełach Arnolda Geulinecx³ ${ }^{3}$ Katarzyna Justyniarska-Chojak - między medycyną a teologią w pracy Hieronima Powodowskiego ${ }^{4}$. Na regulacje prawne praktyki lekarskiej zwraca uwagę Elwira

2 3-4 grudnia 2019 r. odbyła się druga edycja tej konferencji.

3 J. Usakiewicz, Arnold Geulinecx (1624-1669): filozof i medycyna, [w:] Medicina, antiqua mediaevalis et moderna, s. 263-274.

4 K. Justyniarska-Chojak, „Recepta duszna i cielesna przeciw powietrzu morowemu” Hieronima Powodowskiego, [w:] Medicina, antiqua mediaevalis et moderna, s. 233-246. 
Kaczyńska5. W kontekście uwarunkowań kulturowych Jerzy Jastrzębski rozważa wpływ chrześcijańskiej koncepcji caritas na rozwój szpitali ${ }^{6}$. Refleksję o niezmienności pewnych aspektów myślenia o zdrowiu, wraz z refleksją na temat relacji między wiarą a medycyną, przynoszą XVI- i XVII-wieczne opowieści o cudach Matki Bożej Kodeńskiej omówione przez Paulę Wydziałkowską7. W szczególności wspomniane przez autorkę współczesne świadectwa cudownych uzdrowień publikowane na stronie internetowej sanktuarium w Kodniu ${ }^{8}$ przypominają starożytne tabliczki ze świątyni Asklepiosa w Epidauros, które zaświadczały o uzdrowieniach za sprawą bóstwa9 ${ }^{9}$

Zestawione w jednym tomie badania na temat tych różnorodnych miejsc i czasów myśli medycznej wywołują wrażenie ciągłości pewnych koncepcji związanych ze zdrowiem i uzdrawianiem, które utrzymują się przez wieki mimo zmiennego krajobrazu kulturowego. Za najważniejszą koncepcję tego rodzaju uznać możemy wiarę w jedność i współzależność duszy i ciała człowieka, a także człowieka i kosmosu. Jest ona obecna w kulturze zachodniej od czasów starożytnych, dla nas bezpośrednio dostępna przede wszystkim w pismach Platona ${ }^{10}$, który jednak z całą pewnością czerpał z dokonań wcześniejszych myślicieli, w szczególności Pitagorasa"1. W Timajosie Platon opisuje jedność świata materialnego i świata duchowego i przy rozpoznaniu różnic między nimi o opozycyjnym wręcz charakte$r \mathrm{e}^{12}$, łączy je w nierozerwalną całość za pomocą idealnej proporcji13. Zawarty w tym dziele szczegółowy opis funkcjonowania organizmu ludzkiego obrazować ma porządek, poprzez który świat idei (duchowy) wyraża się w świecie materialnym ${ }^{14}$. W jednym ze swych wcześniejszych dialogów, Charmidesie, Platon przedstawia bardziej praktyczny wymiar wiary w jedność duszy i ciała, przytaczając ustami Sokratesa receptę na ból głowy, która składa się z dwóch komponentów - fizycznego (ziele lecznicze) oraz duchowego (zaklęcie):

5 E. Kaczyńska, Najstarsza umowa gwarantująca bezpłatną usługę medyczną, [w:] Medicina, antiqua mediaevalis et moderna, s. 39-58.

6 J. Jastrzębski, Praktyki medyczne i opieka nad chorymi w klasztorach wczesnochrześcijańskich w Górnym Egipcie i Bazylei Kapadockiej, [w:] Medicina, antiqua mediaevalis et moderna, s. 103-120.

7 P. Wydziałkowska, Cuda dokonane za sprawą Matki Bożej Kodeńskiej jako element historii postrzegania choroby i lecznictwa w Rzeczpospolitej XVII-XVIII w., ze szczególnym uwzględnieniem legendarnego cudownego uzdrowienia Mikołaja Sapiehy Pobożnego, [w:] Medicina, antiqua mediaevalis et moderna, s. 291-307.

8 Kodeń. Świadectwa doznanych łask, koden.com.pl/swiadectwa-doznanych-lask [dostęp 29.08.2020].

9 W. Szumowski, Historia medycyny filozoficznie ujęta, Warszawa 1994, s. 87.

10 „Platon pojęcie zdrowia odnosił do stanu równowagi między duszą a ciałem oraz między człowiekiem a światem zewnętrznym, wszechświatem", B. Wojciechowska, Flebotomia i purgowanie czyli o leczeniu w wiekach średnich, Kielce 2019, s. 18.

11 „Platońska koncepcja zdrowia wynika bezpośrednio z pitagorejskiej zasady harmonii. «Wszystko, co jest dobre, jest piękne, a nie ma piękna bez symetrii. Zatem i jestestwo żyjące musi być symetryczne, by być dobrym» (87c). W przypadku zdrowia i choroby, najważniejszą z symetrii jest symetria między duszą i ciałem.", J. Ziaja, Choroby $i$ ich leczenie w ujęciu Platona na tle poglądów lekarzy hipokratejskich, „Archiwum Historii i Filozofii Medycyny" t. 65, 2002, nr 4, s. 451-452.

12 „Czym jest to, co istnieje wiecznie, nie mając początku? Czym zaś jest to, co wciąż na nowo powstaje, lecz nie istnieje wcale? To pierwsze pojąć można rozumem, zawsze pozostaje tym samym. Drugie tworzy mniemania

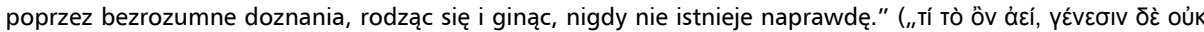

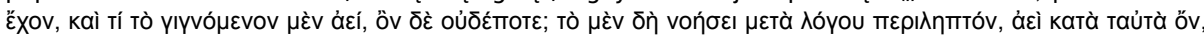

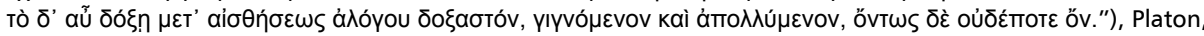
Timajos, 27d-28a (wszystkie tłumaczenia użyte w tekście zostały sporządzone przez autorkę).

13 „Najpiękniejszą z więzi jest ta, która najskuteczniej tworzy jedność ze składającymi się na nią elementami.

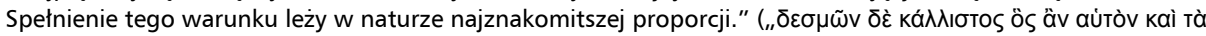

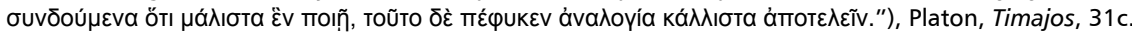

14 "The whole universe, then, ideal and material, is seen to be a single Unity manifesting itself in diversity", R.D. Archer-Hind, The Timaeus of Plato, Londyn - Nowy Jork 1888, s. 33-34. 
Lekarstwem jest pewien liść, a do niego zaklęcie, które, jeśli zaśpiewane w trakcie aplikacji lekarstwa, daje mu całkowitą moc uzdrawiającą, zaś bez zaklęcia nie będzie $z$ tego listka żadnego pożytku ${ }^{15}$.

To ustaliwszy, przechodzi Sokrates Platona do wytłumaczenia takiego stanu rzeczy, powołując się na grecką tradycję medyczną, charakteryzującą się holistycznym spojrzeniem na ciało człowieka: „W myśl tego, mając na względzie całe ciało, przepisują zmianę trybu życia; część starają się wyleczyć poprzez całość"16. Przyznając słuszność zasadzie stojącej za helleńską praktyką lekarską, zwraca jednak uwagę na jej ograniczenie, porównując do koncepcji trackiej, która jako całość traktuje nie samo tylko ciało, lecz ciało wraz z duszą.

Tak, jak nie należy próbować leczyć oczu bez głowy, a głowy bez ciała, tak samo ciała bez duszy. I z tego powodu wiele chorób umyka helleńskim lekarzom - zaniedbują bowiem tę całość, o którą powinni się troszczyć; ponieważ kiedy całość nie ma się dobrze, to i część nie może być w dobrym stanie. Wszelkie dobro i zło ciała oraz człowieka bierze się bowiem z duszy. [...] Duszę natomiast leczy się pewnymi zaklęciami. Zaklęcia są to tego rodzaju piękne słowa, za sprawą których rodzi się

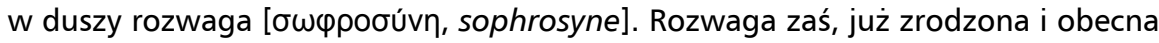
w człowieku, z łatwością przynosi zdrowie tak głowie, jak i reszcie ciała ${ }^{17}$.

Filozof Susan Bredlau w swoim artykule IIlness As a Phenomenon of Being-in-the-world with Others: Plato's Charmides, Kleinman and Merleau-Ponty ${ }^{18}$ przekonuje, że Charmides Platona jest tekstem niezwykle inspirującym do wystawiania utartych mniemań o chorobie i ciele na próbę. Zdaniem autorki nietrudno przyjąć wobec rozmowy na temat bólu głowy z Charmidesa lekceważącą perspektywę, traktując ją jako zaledwie pretekst do podjęcia bardziej ważkiego problemu rozwagi tudzież cnoty zachowywania umiaru ( $\sigma \omega \varphi \rho o \sigma u ́ v \eta$, sophrosyne). Taka postawa zdradza „przywiązanie do pewnego rodzaju Kartezjańskiego dualizmu umysł-ciało i interpretację dyskusji Sokratesa na temat ciała i duszy w kontekście tego przywiązania"19. Poprzez analizę prac Arthura Kleinmana ${ }^{20}$, psychiatry i antropologa,

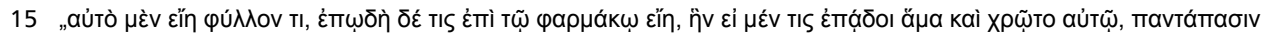

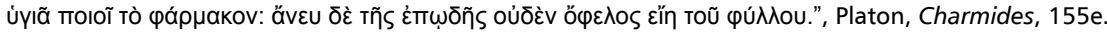

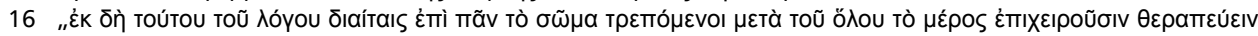

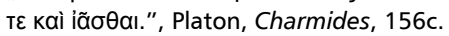

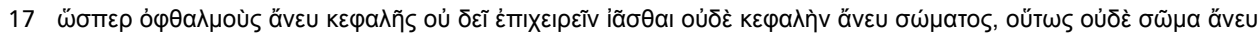

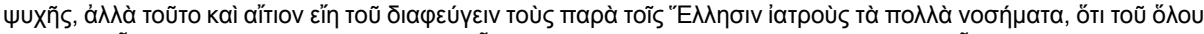

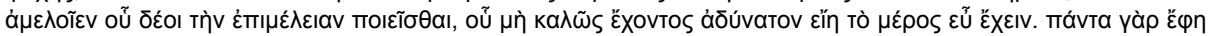

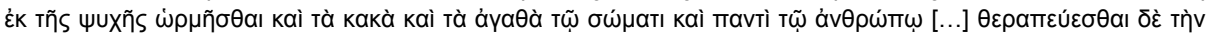

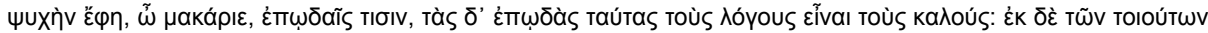

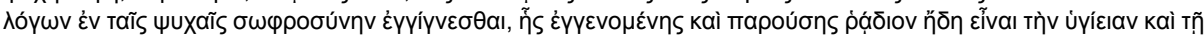

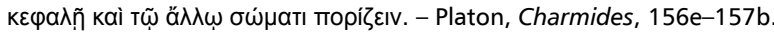

18 S. Bredlau, Illness As a Phenomenon of Being-in-the-world with Others: Plato's Charmides, Kleinman and Merleau-Ponty, "Medical Humanities” opublikowano online 11 grudnia 2018, DOI 10.1136/medhum-2018-011572.

$19, \ldots$,... [eflect a commitment to a form of Cartesian mind-body dualism and an interpretation of Socrates' discussion of body and soul in terms of this commitment", ibid., s. 2.

20 Autorka pisze, cytując Rethinking Psychiatry: from Cultural Category to Personal Experience Kleinmana: „" "In all societies, the body appears to represent both a rich source of symbols for communicating about them social group or the individual forms of misery, much of it socially caused. Bodily complaints can be metaphors of personal, social, and even political distress .» Thus a person's bodily symptoms should be understood in light of her body's culturally specific symbolic status.", ibid., s. 3. 
oraz fenomenologa Maurice'a Merleau-Ponty'ego ${ }^{21}$ argumentuje ona za spojrzeniem na ciało, które jej zdaniem prezentuje także Platon w Charmidesie:

Ciało nie jest po prostu obiektem fizycznym, lecz przede wszystkim doświadczającym podmiotem; ciało jest w gruncie rzeczy naszym sposobem posiadania świata. Analogicznie choroba, zamiast być postrzeganą jako zaburzenie albo wyłącznie fizycznego, albo wyłącznie mentalnego rodzaju, powinna być raczej rozumiana w kontekście bycia-w-świecie [being-in-the-world] z innymi22.

Nawiasem mówiąc, spostrzeżenie autorki o ciele jako sposobie doświadczania świata zbiega się z interpretacją Richarda Dacrego Archera-Hinda Timajosa, wedle której uwikłana w świat materialny dusza zmuszona jest doświadczać tego samego poprzez inne, jedności poprzez różnorodność, wieczności poprzez przemijanie, a siebie samej poprzez ciało $^{23}$. Bredlau porusza szereg arcyciekawych wątków ukrytych w Charmidesie, od nadmiernego pijaństwa jako potencjalnej przyczyny bólu głowy Charmidesa, jego uwarunkowań społecznych, uwikłań politycznych, po rozwagę tudzież sztukę zachowania umiaru

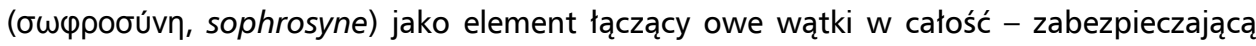
przed przyszłym bólem głowy poprzez umiar w konsumpcji, a w szerszym znaczeniu broniącą państwo przed groźbą tyranii. Używając języka, którym posługuje się autorka, choroba (ból głowy) Charmidesa jest efektem jego bycia-w-świecie, które nie ma wiele wspólnego z rzeczywistą rozwagą.

Koncepcja stojąca za receptą na ból głowy opisaną w Charmidesie, czyli leczenie dwutorowe poprzez działania fizyczne oraz duchowe (zaklęcia lub modlitwy), pojawia się wielokrotnie wśród artykułów składających się na tom Medicina, antiqua mediaevalis et moderna. Historia - filozofia - religia. Warto w tym miejscu zwrócić uwagę, że nieobecność aspektów religijnych i magicznych (niezmiernie istotnych w kulturowym postrzeganiu zdrowia i choroby) w pozytywistycznym modelu historii medycyny Jaromir Jeszke uważa za poważne niedopatrzenie ${ }^{24}$. W omawianej publikacji element duchowy w kontekście magicznym spotkamy na przykład $w$ badaniu leczniczych praktyk magicznych owczarzy karpackich w XIX i XX w. ${ }^{25}$ oraz w studium kulturowo-językowym pojęcia choroby

21 W nawiązaniu do Fenomenologii percepcji Merleau-Ponty'ego Autorka czyni następujące spostrzeżenia na temat relacji umysł-ciało: „the phantom limb seems to be both physiological and psychological, a result of both third-person physical causation and first-person thought, and yet a 'mixed theory of the phantom limb is insufficient since this leaves the question how mind and body interact with each other unanswered.", ibid.

22 „The body, rather than simply being a physical object, is instead, primarily an experiencing subject; the body is fundamentally our way of having a world. Likewise, illness, rather than being conceived of as either an exclusively physical or an exclusively mental disorder, should instead be understood in terms of a person's being-inthe-world with others.", ibid., s.2.

23 R.D. Archer-Hind, op. cit., s. 28-36.

24 „«Wizja świata i człowieka» odbiorców oficjalnych systemów terapeutycznych w dziejach jest więc postrzegana przez badaczy instrumentalnie, z punktu widzenia potrzeb oficjalnego systemu medycznego. Socjolodzy wyróżniają na poziomie kulturowym cztery typy reakcji na chorobę: 1. religijną (znaczenie symboliczne), 2. magiczną (środki rytualne), 3. opiekuńczą (podtrzymująca - znaczenie ekspresywne), 4. medyczną (techniczna, środki instrumentalne). Polska historiografia medyczna niemal wyłącznie koncentruje swoją uwagę na relacji czwartej pomijając milczeniem, tak ważne dla pacjenta trzy pierwsze.", J. Jeszke, Relacje lekarz-pacjent w polskich badaniach historyczno-medycznych, „Archiwum Historii i Filozofii Medycyny” t. 58, 2001, nr 4, s. 453-454.

25 „W rytuale, któremu poddawany był chory, występowały zazwyczaj trzy elementy: 1) odmawianie formuły magicznej (zaklęcia); 2) wykonywanie określonych czynności (gestów); 3) posługiwanie się różnego rodzaju środkami «leczniczymi».", K.P. Woźniak, Bulanda i jego karpaccy pobratymcy. Lecznicze praktyki magiczne owczarzy karpackich w XIX i XX wieku, [w:] Medicina, antiqua mediaevalis et moderna, s. 331. 
w polskim folklorze ${ }^{26}$, w kontekście religijnym zaś przede wszystkim w omówieniu cudów dokonanych za sprawą Matki Bożej Kodeńskiej27 oraz św. Józefa z Kolegiaty w Kaliszu ${ }^{28}$. Bez wątpienia jednak wyrażone w Charmidesie założenia o konieczności równoczesnego leczenia duszy wraz z ciałem najwyraźniej dają się zauważyć w dziele Recepta duszna i cielesna przeciwko powietrzu morowemu Hieronima Powodowskiego omawianym przez Katarzynę Justyniarską-Chojak. Jak zauważa autorka,

niewątpliwie ciekawym zabiegiem było umieszczenie w traktacie wskazówek dotyczących zarówno „recepty cielesnej”, jak i „recepty dusznej”. Powodowski, kaznodzieja i teolog, pozostawił czytelnikom jasny przekaz. Zdrowie duszy w bezpośredni sposób miało wpływać na zdrowie ciała ${ }^{29}$.

Z tego też powodu, na co zwraca uwagę autorka artykułu, Recepta duszna i cielesna przeciw powietrzu morowemu zwieńczona została Modlitwą przeciwko morowemu powietrzu osobliwą. Warto nadmienić (o czym autorka nie wspomina, a co rzuca się w oczy przy lekturze jej artykułu), że Powodowski zdaje się ponadto - świadomie lub nieświadomie - rezonować z myślą platońską, gdy przekonuje o tym, że nie należy bać się śmierci. Jego pogląd o życiu jako „sposobieniu się do śmierci” Justyniarska-Chojak interpretuje jako nawiązanie do piętnastowiecznych ksiąg znanych pod tytułem Ars bene moriendi30, warto jednak zaznaczyć, że nosi on także znamiona podobieństwa z myślą wyrażoną w Fedonie Platona i subtelnie przetworzoną w Rozmowach tuskulańskich Cycerona. Umierający Sokrates w Fedonie przekonuje, że filozofowanie przygotowuje duszę do śmierci,

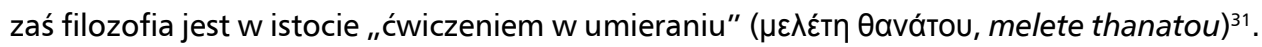
Cyceron zmienia nieco ów przekaz, gdy nawiązuje do tego miejsca Tuskulankach: „Całe życie filozofa, jak sam mówi [Platon], jest kontemplacją śmierci (commentatio mortis)"32. Wersja Cycerońska znajduje się już bardzo blisko „życia jako sposobienia się do śmierci” Powodowskiego. Także Arnold Geulincx, bohater artykułu Joanny Usakiewicz ${ }^{33}$, odnosi się do tej samej starożytnej koncepcji jedności ciała i ducha, naturalnie nie bez późniejszych wpływów. Związek myśli Geulincx z filozofią starożytną (konkretniej platońską), pozostaje nieporuszony przez autorkę artykułu. Tymczasem znów w duchu Platońskiego Fedona, XVII-wieczny filozof twierdzi, że „śmierć nie jest niczym innym niż odłączeniem umysłu od ciała"34. W Fedonie celem filozofii, „ćwiczenia w umieraniu”, jest właśnie odłączenie

26 „Należy zaznaczyć, że ludowy rytuał leczniczy, bazujący na słowie (mówienie) i działaniu (czynienie), utrwalił wiele dawnych sądów na temat funkcjonowania człowieka.", M. Marczewska, Choroba - obraz utrwalony w tekstach folkloru polskiego, [w:] Medicina, antiqua mediaevalis et moderna, s. 344.

27 P. Wydziałkowska, Cuda dokonane za sprawą Matki Bożej Kodeńskiej jako element historii postrzegania choroby i lecznictwa w Rzeczpospolitej XVII-XVIII w., ze szczególnym uwzględnieniem legendarnego cudownego uzdrowienia Mikołaja Sapiehy Pobożnego, [w:] Medicina, antiqua mediaevalis et moderna, s. 291-307.

28 M. Delimata-Proch, Choroby oraz wypadki dzieci w świetle księgi „Cudów y łask za przyczyną (...) Józefa świętego (...) w Kollegiacie Kalliskiey” Stanisława Józefa Kłossowskiego, [w:] Medicina, antiqua mediaevalis et moderna, s. 309-325, w szczególności: „medycy kurujący syna Józefy Smogorzewskiej nie tylko odstąpili od pacjenta, wskazując na beznadziejne rokowania, ale przede wszystkim uznali świętego Józefa za «naypewnieysze i nayskutecznieysze lekarstwo»", s. 322.

29 K. Justyniarska-Chojak, op. cit., s. 245.

30 Ibid., s. 241.

31 Platon, Fedon, 80e-81a.

32 „Tota enim philosophorum vita, ut ait idem, commentatio mortis est.”, Cyceron, Rozmowy tuskulańskie, 1.74.

33 J. Usakiewicz, op. cit., s. 263-274.

34 Ibid., s. 271. 
duszy od ciała, to jest wyzwolenie umysłu z uwarunkowań materialnych. W podobieństwie do myśli platońskiej Geulincx pojmuje człowieka jako „umysł wcielony” (mens incorporata) ${ }^{35}$ i zwraca uwagę na specyficzny status istoty ludzkiej na pograniczu świata duchowego i materialnego, nazywając go „kondycją ludzką" (conditio humana) ${ }^{36}$. W odróżnieniu od prezentowanej przez Platona koncepcji współzależności duszy i ciała, Arnold Geulincx uważał ich współistnienie za pozbawione wzajemnych oddziaływań, które wyjaśniał teorią okazjonalizmu ${ }^{37}$. Platońska myśl rezonuje w jego pismach po raz kolejny, gdy deklaruje, że „tak, jak ma się zdrowie do ciała, tak prawdziwa filozofia ma się do ducha". W istocie całkiem podobnymi słowami moglibyśmy podsumować receptę na ból głowy z Charmidesa.

Praktyki medyczne istnieją zawsze w kontekście określonego rozumienia człowieka i otaczającego go świata oraz stosunków między nimi. Koncepcja człowieka jako istoty łączącej w sobie świat materialny z duchowym wymagać będzie leczenia obu aspektów tej dwoistej egzystencji - poprzez jednoczesne użycie środków fizycznych i metafizycznych, z których te drugie mogą być realizowane przez filozofię, religię, magię czy sztukę.

Medycyna jako nauka praktyczna odnosi się w swym zakresie do określonego sposobu definiowania miejsca człowieka w świecie. Ponieważ sposób ów, zarówno w ujęciu diachronicznym, jak i synchronicznym, jest różny w odmiennych kulturach, społecznościach, konfesjach, warstwach społecznych itd., wywiera to realny wpływ na określenie przez lekarzy celów ich działalności praktycznej, jak również na wybór metod, które umożliwiają ich realizację ${ }^{38}$.

Dwie nadrzędne orientacje badawcze względem historii medycyny opisała i zanalizowała Bożena Płonka-Syroka w swoim artykule z 1995 r., Społeczno-kulturowy kontekst historii medycyny - przegląd koncepcji i propozycje badawcze:

Model pozytywistyczny (lekarski) i antypozytywistyczny (humanistyczny) w polskiej XX-wiecznej historiografii medycyny stanowią komplementarne ujęcie dziejów medycyny. [...] Subiektywistyczny i obiektywistyczny punkt widzenia, podkreślanie nierozerwalnej więzi kontekstu społeczno-kulturowego (przez model humanistyczny) tworzenia się wiedzy medycznej i marginalizowanie owej więzi (przez model lekarski) tworzą odrębne wizje dziejów nauki ${ }^{39}$.

Ujęcie pozytywistyczne skupia się wokół medycyny współczesnej jako punktu dojścia, podczas gdy ujęcie antypozytywistyczne bada, czym była medycyna w czasach minionych. Zbiór pod redakcją Sylwii Konarskiej-Zimnickiej, Lucyny Kostuch i Beaty Wojciechowskiej bez wątpienia zaliczyć możemy do nurtu humanistycznego. Zdradza to zresztą już podtytuł: „historia - filozofia - religia”, zapowiadając dialog między dyscyplinami oraz uwzględnienie kontekstu kulturowego.

37 Ibid., s. 266-271.

38 B. Płonka-Syroka, Antropologia wiedzy jako nowa perspektywa badań nad historią medycyny, „Rocznik Antropologii Historii" r. 8, 2018, nr 11, s. 46-47.

39 Eadem, Społeczno-kulturowy kontekst historii medycyny - przegląd koncepcji i propozycje badawcze, „Medycyna Nowożytna. Studia nad Historią Medycyny" t. 2, 1995 z. 1, s. 20. 
Zdaniem Hansa-Jörga Rheinbergera historia nauki siłą rzeczy wymaga łączenia perspektyw wypracowanych przez nauki przyrodnicze i humanistyczne:

Najważniejsze i najbardziej interesujące w historii nauki jest to, że jest ona dziedziną, w której w pewnym stopniu od samego początku z jednej strony niemożliwe jest uniknięcie zetknięcia z naukami przyrodniczymi, a z drugiej, z metodologicznej perspektywy, nieodzowne jest sięgnięcie do nauk humanistycznych i społecznych. Nie funkcjonuje ona bez tych dwóch perspektyw. Obydwa obszary - nauki przyrodnicze oraz nauki humanistyczne i społeczne - są w niej obecne. Uważam to za ekscytujące - tworzą się potencjalne napięcia (Reibungspotential) w znaczeniu twórczych energii. Historia nauki w znacznym stopniu przyczyniła się do rozwoju procesów refleksji kulturologicznej i to właśnie na bazie tej hybrydowej struktury ${ }^{40}$.

Wielowymiarowość historii medycyny objawia się w różnorodności tematyk podjętych w książce Medicina, antiqua mediaevalis et moderna. Historia - filozofia - religia. Redaktorzy tomu, Sylwia Konarska-Zimnicka, Lucyna Kostuch i Beata Wojciechowska, podkreślają we wprowadzeniu, że między dziedzinowy charakter publikacji zdeterminowany jest bogactwem kontekstów, w jakich obraca się historia medycyny:

Badania w obszarze historii medycyny wymagają łączenia elementów dorobku różnych dyscyplin nauki: medycyny, przyrodoznawstwa, historii, historii nauki, historii religii, historii sztuki, filozofii, teologii, filologii, archeologii itd. (s. 7).

\section{Bibliografia}

\section{Źródła}

Cyceron, Rozmowy tuskulańskie, wyd. M. Pohlenz, Leipzig 1918.

Kodeń. Świadectwa doznanych łask, koden.com.pl/swiadectwa-doznanych-lask [dostęp 29.08.2020]

Platon, Charmides, Fedon, Timajos, [w:] Platonis opera, wyd. J. Burnet, Oxford 1903.

\section{Literatura przedmiotu}

Archer-Hind R.D., The Timaeus of Plato, Londyn - Nowy Jork 1888.

Bredlau S., IIIness As a Phenomenon of Being-in-the-world with Others: Plato's Charmides, Kleinman and Merleau-Ponty, „Medical Humanities”, opublikowano online 11 grudnia 2018, DOI 10.1136/medhum-2018-011572.

Jeszke J., Relacje lekarz-pacjent w polskich badaniach historyczno-medycznych, „Archiwum Historii i Filozofii Medycyny" t. 58, 2001, nr 4, s. 453-465.

Medicina antiqua, medievalis et moderna. Historia - filozofia - religia, red. S. Konarska-Zimnicka, L. Kostuch, B. Wojciechowska, Kielce 2019.

Płonka-Syroka B., Antropologia wiedzy jako nowa perspektywa badań nad historią medycyny, „Rocznik Antropologii Historii” r. 8, 2018, nr 11, s. 39-74, DOI 10.25945/ ct6x-1h31.

40 J. Surman, Historyzowanie nauki lub jak nowe przychodzi na świat. Rozmowa z Hansem-Jörgiem Rheinbergerem, „Prace Komisji Historii Nauki PAU” t. 14, 2015, s. 301-302. 
Płonka-Syroka B., Społeczno-kulturowy kontekst historii medycyny - przegląd koncepcji i propozycje badawcze, „Medycyna Nowożytna. Studia nad Historią Medycyny” t. 2, 1995, z. 1, s. 5-21.

Surman J., Historyzowanie nauki lub jak nowe przychodzi na świat. Rozmowa z Hansem-Jörgiem Rheinbergerem, „Prace Komisji Historii Nauki PAU” t. 14, 2015, s. 291-306.

Szumowski W., Historia medycyny filozoficznie ujęta, Warszawa 1994.

Wojciechowska B., Flebotomia i purgowanie czyli o leczeniu w wiekach średnich, Kielce 2019.

Ziaja J., Choroby i ich leczenie w ujęciu Platona na tle poglądów lekarzy hipokratejskich, „Archiwum Historii i Filozofii Medycyny” t. 65, 2002, nr 4, s. 443-456.

mgr Katarzyna Borkowska, asystent w Pracowni Historii Nauk Przyrodniczych i Medycznych Instytutu Historii Nauki im. L. i A. Birkenmajerów PAN, doktorantka Instytutu Filologii Klasycznej UW. Pisze pracę pod tytułem Cyceron i Platon: tłumaczenia, parafrazy, nawiązania pod kierunkiem prof. dr hab. Mikołaja Szymańskiego.

e-mail: kasia.bor@gmail.com

Data zgłoszenia artykułu: 12 października 2020

Data przyjęcia do druku: 20 października 2020 